\section{Research}

\section{${ }^{*}$ Corresponding author}

Wilson I.B. Onuigbo, MD, PhD

Founder-Director

Medical Foundation and Clinic

8 Nsukka Lane, Enugu 400001

Nigeria

Tel. +2348037208680

E-mail:wilson.onuigbo@gmail.com

\section{Volume 1 : Issue 1}

Article Ref. \#: 1000SROJ1104

\section{Article History}

Received: October $12^{\text {th }}, 2014$

Accepted: January 24 $4^{\text {th }}, 2015$

Published: January $27^{\text {th }}, 2015$

\section{Citation}

Onuigbo WIB. Epidemiologic analysis of the surgical specimens of breast carcinosarcomas examined at a Reference Laboratory in a Nigerian Community. Surg Res Open J. 2015; 1(1): 25-27. doi: 10.17140/SROJ-1104

\section{Copyright}

(C2014 Onuigbo WIB. This is an open access article distributed under the Creative Commons Attribution 4.0 International License (CC BY 4.0), which permits unrestricted use, distribution, and reproduction in any medium, provided the original work is properly cited.

\title{
Epidemiologic Analysis of the Surgical Specimens of Breast Carcinosarcomas Examined at a Reference Laboratory in a Nigerian Community
}

\author{
Wilson I.B. Onuigbo*
}

Founder-Director, Medical Foundation and Clinic, 8 Nsukka Lane, Enugu 400001, Nigeria

\section{ABSTRACT}

The idea that carcinoma and sarcoma can exist together dated to as early as 1804 . Pictorial illustrations of this phenomenon appeared by 1882 . Nowadays, with regard to the breast, it is reportedly rare, there being but the documentation of one or two cases. Therefore, i.e. a series of 12 cases is presented from one ethnic group in Nigeria. The ages ranged from 22 to 52 years (average, 35 years). Two cases were diagnosed clinically as benign, 2 others as Cystosarcoma Phyllodes and the rest as carcinoma. A $2 \mathrm{~cm}$ wedge was submitted whereas the rest ranged up to $20 \mathrm{~cm}$ in size. The appearances were described often as huge, fleshy and fungating. The right: left ratio was 1.4:1. Most patients were attended to at the cosmopolitan Enugu Teaching Hospital, the rest being from the hinterland.

KEYWORDS: Breast; Carcinosarcoma; Reference Laboratory; Nigeria.

\section{INTRODUCTION}

The concept of the co-existence of not only carcinoma but also sarcoma was known for many years. Thus, going by my historical collections, Abernethy, ${ }^{1}$ of the fascia eponym, wrote concerning "carcinomatous sarcoma." Indeed, he noted that "the disease extends through the medium of the absorbing vessels." By 1883, David Finlay ${ }^{2}$ of the Middlesex Hospital of London presented to the Pathological Society of that City the illustrations of the different carcinomatous and sarcomatous components found in the one patient's fibroid uterus (Figures 1 and 2).

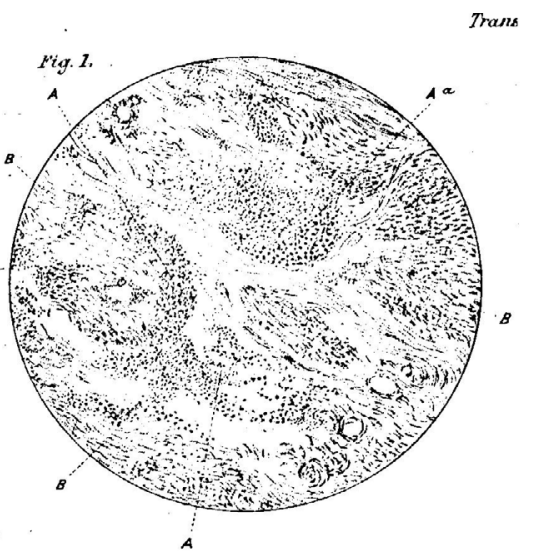

Figure 1: Drawings from the cited reference: a section of the growth under a low power. A refers to areas of rounded-cell growth. B refers to areas of spindle-cell growth.

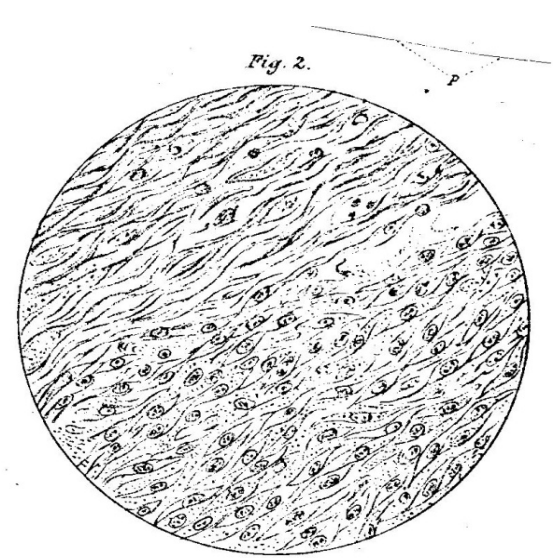

Figure 2: Represents a portion where an area of spindle-shaped cells closely adjoins a portion of the normal structure of the fibromyoma. 
Nowadays, with particular reference to the breast, contributors from countries as far apart as Jamaica, ${ }^{3} \mathrm{USA}^{4}$ and Islamabad ${ }^{5}$ emphasized the rarity of mammary carcinosarcoma as contained in the literature. Therefore, the Nigerian picture is subjoined in terms of the epidemiologic picture based on an ethnic group called the Igbos or Ibos. ${ }^{6}$ The total was possible because of the establishment of a histopathology data pool as was proposed by a Birmingham, UK group. ${ }^{7}$

\section{INVESTIGATION}

The establishment in 1970 of a Reference Pathology Laboratory serving the large ethnic group called the Igbo's who lives mainly in the Eastern Region of Nigeria served until other laboratories came on stream by 2000. During this period, the author was the sole pathologist. This facilitated the analysis of surgical specimens. The only proviso was that clinical details must be supplied in the Standard Request Form. Incidentally, as many as 420 cases of teenage fibro adenomas were encountered during this period. ${ }^{8}$ Concerning the special tumor called carcinosarcoma, it was not until 1986 that the first case was recognized personally. It is of interest to reproduce my very report as thus: (Table 1)

The microscopic appearances are odd. There are two components, each showing high mitotic activity. On the one hand, there are deeply basophilic epithelial elements which form recognizable acini in places and are epidermoid in one focus. On the other hand, there is a granulation-like component in which hyperchromatic bizarre cells are scattered.

\section{DISCUSSION}

Now, these cases pertain to biopsy materials, whose parameters do not include surgical treatments and outcomes. Therefore, these aspects are outside the scope of this paper. Accordingly, epidemiologic considerations alone are deemed to be apposite.

Firstly, there are the above histological descriptions which are typical. It is to be noted that this particular example displays malignancy of two different breast tissues. Such tissues are regarded as being homologous. In fact, the encyclopedic Ackerman's Surgical Pathology ${ }^{9}$ distinguished between the homologous type, which displays the malignant change of the component tissues, as opposed to the heterologous group which may show "skeletal muscle, cartilage, bone or fat."

Secondly, apart from the three cited examples concerning the breast from Jamaica, ${ }^{3} \mathrm{USA}^{4}$ and Islamabad, ${ }^{5}$ there are interesting records from the UK, ${ }^{10}$ Taiwan, ${ }^{11}$ and Morocco, ${ }^{12}$ in respect of another female organ, i.e., the ovary.

Thirdly, there is the debate in the UK as to "whether a satisfactory histopathology service can ever be delivered to a hospital remote from the providing pathologists and their laboratory." "13 Certainly, in this series, most requests were made in Enugu where the Pathology Laboratory is situated. However, requests made by surgeons practicing in Missionary Hospitals and Private Hospitals situated in the hinterland of this developing community were attended to. In point of fact, the statistically the usefulness of such a designated laboratory has been

\begin{tabular}{cllllllll}
\hline Series & Patient & Lab No & Age & Description & $\begin{array}{l}\text { Size } \\
(\mathbf{c m})\end{array}$ & Side & Appearance & Town \\
\hline 1 & A I & 011196 & 36 & Carcinoma & 2 & $\mathrm{R}$ & Ulcer & Afikpo \\
2 & A N & $52 / 91$ & 33 & Fibroadenoma & 4 & L & Lump & Enugu \\
3 & I C & $584 / 88$ & 22 & Fibrocystic & 4 & $\mathrm{R}$ & Huge & Umuahia \\
4 & I F & 040555 & 37 & Carcinoma & 12 & $\mathrm{~L}$ & Lump & Enugu \\
5 & N C & 06122 & 49 & Carcinoma & 8 & $\mathrm{~L}$ & Lump & Owerri \\
6 & N V & $416 / 87$ & 24 & Carcinoma & 16 & $\mathrm{R}$ & Lump & Enugu \\
7 & O C & $249 / 87$ & 41 & Carcinoma & 9 & $\mathrm{R}$ & Fungating & Enugu \\
8 & O N & $1607 / 87$ & 37 & Carcinoma & 18 & $\mathrm{~L}$ & Fungating & Enugu \\
9 & O E & 9205137 & 52 & Carcinoma & 7 & $\mathrm{~L}$ & Lump & Enugu \\
10 & U E & 001092 & 28 & Cystosarcoma & 20 & $\mathrm{R}$ & Fishy & Ehime \\
11 & O P & 9301116 & 25 & Cystosarcoma & 11 & $\mathrm{R}$ & Mass & Enugu \\
12 & O C & $2224 / 86$ & 42 & Carcinoma & 4 & $\mathrm{R}$ & Lump & Enugu \\
\hline
\end{tabular}

Table 1: Epidemiologic data: Shows the findings concerning this unique tumour from 1986 to 2006. 
demonstrated by courtesy of a British journal ${ }^{14}$ and a Nigerian journal. ${ }^{15}$ Moreover, the present study provides concrete evidence that surgeons trained in a cosmopolitan center can opt to render skilled professional services in remote hospitals.

Finally, an interesting question arises as follows; "Of what use is breast cancer classification?" From the Netherlands, Weigelt's group ${ }^{16}$ sought the refinement of cancer classification along molecular lines. As they summarized, "Taken together, our results represent a step forward towards a taxonomy that not only best reflects the biology of breast cancers, but also paves the way for a refinement in the prognostication of breast cancer patients and the identification of novel tailored therapies." From UK and Australia, Reis-Filho and Lakhan, ${ }^{17}$ who classified "Carcinosarcoma" as "Metaplastic Carcinoma," were able to conclude with an eye on the future prospects thus:

Understanding the molecular basis of histological features is a crucial step for unravelling the complexity and heterogeneity of breast cancer and for effectively tailoring the therapies of breast cancer patients. Let us hope that these efforts pave the way for better classification systems and hence more tailored management of patients with cancer.

\section{REFERENCES}

1. Abernethy J. Surgical observations containing a classification of tumours. London: Longman and Reeves. 1804; 72.

2. Finlay DW. Fibro-myoma of the uterus, becoming sarcomatous, with secondary growths in pleura, heart and kidney. Trans Pathol Soc London. 1883; 34: 177-180.

3. Harris M, Persaud V. Carcinosarcoma of the breast. J Pathol. 1974; 112: 99-105.

4. Esses KM, Hagmaier RM, Blanchard SA, et al. Carcinosarcoma of the breast: two case reports and review of the literature. Cases Journal. 2009; 2: 15. doi: 10.1186/1757-1626-2-15

5. Abbasi MA, Mahmood H, Faheem M, et al. Carcinosarcoma of the breast. J Coll Phy Surg Pakistan. 2012; 22: 333-334.

6. Basden GT. Niger Ibos. London: Frank Cass \& Co Ltd. 1966; 417.

7. Macartney JC, Rollason TP, Codling BW. Use of a histopathology data pool for epidemiological analysis. J Clin Pathol. 1980; 33: 351-359.

8. Onuigbo WIB. Breast fibroadenoma in teenage females. Turkish Journal of Pediatrics. 2003; 45: 326-328.

9. Rosai J. Ackermam's Surgical Pathology. (2(8) Ed). St Louis: Mosby. 1996; 1423.
10. Chang J, Sharpe JC, A'Hern RP, Fisher C, et al. Carcinosarcoma of the ovary: Incidence, prognosis, treatment and survival of patients. Ann Oncol. 1995; 6: 755-758.

11. Chang JS, Chua C-C, Lee C-C. Borderline mucinous cystic ovarian tumor with mural nodules (carcinosarcoma). Ann Saudi Med. 2012; 32: 415-420.

12. Belbaraka R, Taleb A, Errihani H. A rare tumour of the ovary: Carcinosarcoma. J Med Cases. 2010; 1(2): 55-57.

13. Lilleyman J. From the President. Bull Roy Coll Pathol. 2002; 117: 3 .

14. Onuigbo WIB, Mbanaso AU. Urban histopathology service for a remote Nigerian hospital. Bull Roy CollPathol. 2005; 132: $32-34$.

15. Onuigbo WIB, Anyaeze CM. Biopsy service for surgical practice in mission hospital. Owerri Med J. 2009; 3: 7-10.

16. Weigelt B, Horlings HM, Kreike B, et al. Refinement of breast cancer classification by molecular characterization of histological special types. J Pathol. 2008; 216: 141-150. doi: 10.1002/path.2407

17. Reis-Filbo JS, Lakhani SR. Breast cancer special types, why bother? J Pathol. 2008; 216: 394-398. doi: 10.1002/path.2419 